\title{
Ozone applications in veterinary oncology [abstract]
}

\section{Susana Gabriela Gayon-Amaro, Eduardo Flores-Colin}

Ozein Vet Klinike

\section{ABSTRACT}

\section{OPEN ACCESS}

\section{Citation}

Gayon-Amaro SG, Flores-Colin E. Ozone applications in veterinary oncology [abstract]. Proceedings of The World Conference on Ozone Therapy in Medicine, Dentistry and Veterinary. Ancona (Italy). September 22nd - 23rd - 24th, 2017. J Ozone Ther. 2019;3(4):18-19. doi: 10.7203/ jo3t.3.4.2019.15423

\section{Academic Editor}

Jose Baeza-Noci,

School of Medicine, Valencia

University, SPAIN

\section{Editor}

World Federation of Ozone Therapy, Bolgna, ITALY

\section{Received}

June 17, 2019

\section{Accepted}

December 08, 2019

Published

December 30, 2019

\section{Intellectual Property}

Susana Gabriela Gayon-Amaro.

This is an open access article distributed under the terms of the Creative Commons Attribution License (CC BY 4.0), which permits unrestricted use, distribution, and reproduction in any medium, provided the original author and source are credited.

\section{Author Information}

Email: gayonamaro@gmail.com
Purpose: To evaluate the clinical improvement of 5 patients (four dogs and one Panthera leo krugeri) diagnosed with neoplasic pathologies treated with ozone therapy under adjusted protocols for each patient.

Patients and methods: Five patients were presented to veterinary consultation for the diagnose of different injuries using cytology, blood examination and imagenology in some cases. According to the diagnose (a female dog with mammary adenocarcinoma, another with vaginal adenocarcinoma, a male dog with basal cells tumour in the scrotum, a young male dog with a periosteal reaction radiographically compatible with osteosarcoma and a male white lion with a melanoma in the lower eyelid) the ozone protocol was established using combinations of local infiltration, topic instillation of ozonized oil, major and minor autohemotherapy and rectal insufflations.

Results. The results showed an improvement of general state of the patients, decrease size of tumor of patient 1 and complete remission in patient 2 (adenocarcinoma) after ultrasound studies of annual control. In patient diagnosed with osteosarcoma, the active oncological process showed in the first radiological study appeared inactive in the second one, claudication and muscle atrophy of affected limb complete disappeared. Cytology of patient 4 shows total absence of basals cells. In patient 5 (melanoma) zookeepers report absence of exudates and pruritus with normal appetite.

Discussion: There are no clinical reports of the use of ozone in oncological veterinary patients but there are many preclinical papers and human case reports about ozone for cancer treatment [1, 2, 3, 4].

Conclusion: Based on that, it is possible to conclude that established protocols were capable of improve quality of life of the patients avoiding metastatic process and tumoral growth.

\section{References:}

1. Menéndez CS, González AR, Ledea LO, Hernández RF, León FO, Díaz GM. Ozono: Aspectos básicos y aplicaciones clínicas. Primera edición. Cuba. Editorial CENIC Centro Nacional de Investigaciones Científicas. 2008. P. 188-194

2. Clavo B, Pérez JL, López L, Suárez G, Lloret M et al. Ozone Therapy for Tumor Oxygenation [independent article]. Spain. Oxford University Press. 2004; Vol. 1 (1): 93-98

3. Menéndez S, Cepero J, Borrego L. Ozone Therapy in Cancer Treatment: State of Art. Ozone: Sci. \& Eng.2008; Vol. 30 (6): 398-404. 
4. Scherbatyuk TG. Experimental research of biological effects of ozone therapy and radiation therapy in cancer animals [Congress abstract]. IAO 17th World Ozone Congress- Strasbourgh 2005. 